Columbia Law School

Scholarship Archive

1996

\title{
Cooperating Defendants: The Costs and Benefits of Purchasing Information from Scoundrels
}

Daniel Richman

Columbia Law School, drichm@law.columbia.edu

Follow this and additional works at: https://scholarship.law.columbia.edu/faculty_scholarship

Part of the Law Commons

\section{Recommended Citation}

Daniel Richman, Cooperating Defendants: The Costs and Benefits of Purchasing Information from Scoundrels, 8 FED. SENT'G REP. 292 (1996).

Available at: https://scholarship.law.columbia.edu/faculty_scholarship/749

This Article is brought to you for free and open access by the Faculty Publications at Scholarship Archive. It has been accepted for inclusion in Faculty Scholarship by an authorized administrator of Scholarship Archive. For more information, please contact scholarshiparchive@law.columbia.edu. 


\section{COOPERATING DEFENDANTS: THE COSTS AND BENEFITS OF PURCHASING INFORMATION FROM SCOUNDRELS}

\author{
Daniel C. Richman*
}

Only the most unreflective prosecutor can avoid feeling ambivalent about cooperation. Without the assistance of defendants willing to trade testimony for the expectation of sentencing discounts, many cases worth prosecuting could not be made. But if a prosecutor maintains any distance from these defendants - as he must $\mathrm{t}^{1}$ - he is bound to be troubled by the magnitude of the discounts that the federal system (like other systems) gives to cooperators, many of whom rank as some of the most odious people he has ever met.

The idea of purchasing testimony through sentencing discounts has a long history, of course, ${ }^{2}$ as have condemnations of those who "snitch." ${ }^{\text {3 }}$ The discounts, however, have become far more dramatic under the federal sentencing guidelines and the statutory mandatory minimums, whose harsh rigidity can effectively be turned off upon a prosecutor's certification that the defendant has rendered "substantial assistance" within the meaning of $\S 5 \mathrm{~K} 1.1$ and 18 U.S.C. $§ 3553(\mathrm{e}) .^{4}$ These discounts, whose magnitude is primarily a function of a cooperator's value to the government, present a special challenge to a regime committed to proportionality and to sentences that reflect offense seriousness. Can this disruption can be justified?

\section{The Costs of the Cooperator System \\ A. Sentencing Equity}

From the standpoint of sentencing equity, one of the most unfortunate aspects of any system that rewards cooperation is that it can favor the most culpable defendants. The "mopes" in a criminal organization might not have much information to trade, even were they willing to cooperate; the kingpin or lieutenant is well placed to render "substantial assistance," often by testifying against criminal subordinates. ${ }^{5}$ And the adverse effects of such inequalities in the distribution of information can be worsened when kingpins endeavor to provide subordinates with lawyers who advise their clients against even trying to cooperate. ${ }^{6}$

The role that defense attorneys play in exacerbating the inequities of our cooperation system may well go beyond the classic "house counsel" scenario. As a prosecutor, I often had the nagging feeling that the chief difference between the cooperator and the non-

* Associate Professor, Fordham Law School. A.B. Harvard, 1980; J.D. Yale Law School, 1984; Assistant United States Attorney in the Southern District of New York (1987-92). cooperating defendant was the attitude of defense counsel to the venture - an attitude often more reflective of the lawyer's personal predilections than her client's interests. A lazy or overextended attorney can push a defendant into cooperating as a way of getting rid of the case. The attorney whose adversarial zeal is powered by economic self-interest may discourage clients from cooperating, striving to develop a reputation for standing fast against the government - a reputation that appeals to the repeatplayers who populate the high end of the market for legal services. And the ideologically committed lawyer can shrink from counseling an alliance with the overpowering state. The scenarios are certainly not inevitable, but they are all too common. Because defendants are ill-equipped to properly assess the risks and benefits of cooperation before they choose a lawyer, the critical role that attorneys play in cooperation decisions presents yet another challenge to a sentencing scheme aspiring to reflect moral desert.?

The foregoing factors would plague any system that gave cooperators sentencing discounts commensurate with the value of their information or testimony. The specific mechanism that the guidelines use for rewarding cooperation, however, is in itself a separate source of potential sentencing inequities. By conditioning any "substantial assistance" departure upon the government's motion, $\S 5 \mathrm{~K} 1.1$ and $\S 3553(\mathrm{e})$ give prosecutors a potent, perhaps even necessary, tool for ensuring that defendants cooperate fully. But government control over the possibility - and, to some extent, the degree ${ }^{8}$ - of such departures has generally been exercised with an insufficient commitment to treating like defendants alike.

To be sure, many U.S. Attorney's Offices try to promote uniformity by funnelling these issues through a standing committee. Yet disparities remain, both within offices and across districts - perhaps because only the line Assistant responsible for a case can truly assess whether a cooperator has been forthcoming and truthful. Nor are these disparities amenable to judicial review: In the absence of a cooperation agreement, the government has virtually unfettered discretion as to when or whether it moves under $\S 5 \mathrm{~K} 1.1$ and $\S 3553(\mathrm{e}){ }^{9}$. Where there is an agreement, its provisions will generally leave the government with the same extent of discretion. ${ }^{10}$ Not surprisingly, the government's standards for "substantial assistance" have been found to vary greatly." And even were judges able to impose greater uniformity in such standards, they would not likely hear about yet another aspect of disparity: the readiness of some prosecutors to certify "substantial assistance" where none was given, simply to allow a sympathetic defendant to escape a harsh guideline sentence. ${ }^{12}$

\section{B. General Deterrence}

The costs of our cooperation system are not limited to its impairment of sentencing equity. They 
also include its effect on general deterrence. The issue is complex: The use of cooperators does increase the likelihood that their accomplices will be convicted. ${ }^{13}$ The lure of deep sentencing discounts may even destabilize a criminal conspiracy before the government initiates a formal prosecution; such is the information-forcing power of the Prisoner's Dilemma. One must wonder at the damage done to the force of our laws, however, when murderers "walk" because they were fortunate enough to have others to "rat" on. ${ }^{14}$

As the evocative slang suggests, the issue is not simply one of deterrence. Our discomfort with "snitching" runs deep. Perhaps moral opprobrium attaches only to the "snitch," and not the government or society that profits from his use. Yet this certainly was not true in the days of Joseph McCarthy, ${ }^{15}$ and I am not sure it is true today.

\section{Perjury}

Our discomfort may also reflect concern that the testimony of cooperators is suspect. The risk that an unscrupulous prosecutor will use his perceived influence over sentencing to coerce or encourage a cooperator to manufacture or shade testimony is always present. Moreover, there is the perhaps greater risk that a cooperator will independently try to be "helpful" to a prosecutor, in hopes of greater leniency, and that the prosecutor will not be able to separate the truth from the "icing." The prosecutor fully equipped to assess the truthfulness of a cooperator's testimony would probably not have needed to cut a deal in the first place.

To the extent that a cooperator lies, or that all cooperators have a tendency to lie, the question of whether we can justify the disruption to sentencing equity and the diminution of respect for law attributable to our cooperation system might be easily resolved. But there is no such easy answer because we lack any hard data as to the extent of such perjury. Defense counsel will routinely argue to juries that snitches will say anything to curry favor with the government, and I suspect that many lawyers actually believe that (except when they represent a cooperator they think deserving of leniency). Prosecutors are convinced that, over time, their feel for cases enables them to detect and deter cooperator perjury; and they are confident that, should the occasion arise, they would have the courage mid-trial to proclaim their star witness a liar. The truth about cooperator reliability is obviously somewhere between these poles, but we know not where, and our ignorance on this score is one of the most troubling aspects of cooperation.

Certainly much truthful testimony is gained. The question therefore becomes whether those gains justify the costs.

\section{The Benefits of the Cooperator System}

To ask how important cooperator assistance is to law enforcement raises an empirical question, but one with moral overtones. In the first instance, this might be taken as a question of whether we need to be devoting so many resources (including the costs of a disrupted sentencing scheme) to the kinds of cases requiring cooperator testimony. I do not believe that this is a fruitful line of inquiry, however.

The government is most likely to "purchase" accomplice testimony where it cannot obtain equally effective evidence from eyewitnesses, victims, documents, and other "untainted" sources. The most likely setting for cooperator testimony will thus be in a case involving secretive conduct and no available victim. Such cases are not amenable to easy classification, but they certainly include murder, corruption, organized crime, as well as narcotics prosecutions. It would simply be misleading to link an assessment of the need for cooperators to the debate on the wisdom and propriety of the "War on Drugs."

Moreover, although cases where the cooperating kingpin gets a lower sentence than his subordinates are troubling, the more common scenario occurs when a criminal organization's leaders, whose distance from street-level activity insulates them from informants, undercovers, and surveillance, are brought down by a cooperating witness recruited from the lower or middle ranks of the conspiracy. Without such testimony, the most culpable players might never get prosecuted. The ultimate effect of cooperation on horizontal equity is thus an open question.

The justification of cooperators as a necessary evil in part rests on the assumption that prosecutors will use cooperator testimony only as a last resort. This assumption lacks a firm empirical basis. Doubtless, some prosecutors, out of risk aversion or laziness, will "overbuy" - signing up cooperators where the case would be strong enough without them, or where additional investigative efforts could turn up alternative sources of evidence. The problem might not be significant were the government to focus on the price it must pay in jury appeal when its case rests on cooperator testimony. But prosecutors are notoriously greedy when it comes to evidence, and the urge to get the "inside" story of a conspiracy for which-absent cooperator testimony-there is only external proof, however strong, can be hard to resist.

The "overbuying" scenario is troubling, but not a serious challenge to the whole notion of purchasing testimony with sentencing discounts. Such a challenge, though, comes from those who suggest that, rather than trade with cooperators, the government should obtain convictions, by plea or trial, and then procure testimony through grants of immunity. Any realistic analysis, however, shows this option to 
be illusory. As most prosecutors soon learn, compulsion orders and the threat of perjury charges are generally not effective against a defendant who chooses not to implicate his co-conspirators. Perjury cases are rarely brought, hard to prove, and unlikely to add much time to sentences that have already been or will be imposed for serious crimes. If truthful information is to be obtained from criminals, it generally must be paid for, and rarely can be coerced.

Sentencing discounts to cooperators may thus be the only way to get critical testimony in a large class of cases worth prosecuting. But are the discounts unnecessarily large? If our goal is to minimize the disruption to the guidelines' equitable goals attributable to such discounts, limiting them to the minimum "price" that defendants would accept for their testimony, I suspect that our prices are inflated across the board. Yet the explanation for this may also be related to fairness concerns. The sentences given to cooperators can reflect not merely consideration for testimony but also the liberation of judges from the constraints of a sentencing regime they deem overly harsh. ${ }^{16}$ Once again we see the clash between individualized fairness and horizontal equity that characterizes nearly all guideline discussions.

Could we minimize the disruption by taking control of cooperation departures out the prosecutors' hands? I doubt it. Perhaps judges would be more apt than prosecutors to disingenuously certify "substantial assistance" where none was given, in order to accommodate the especially sympathetic defendant. But there is little basis for believing that. My own view is that, having lived with a case longer and having a better feel for its factual nuances, prosecutors are particularly well suited to serve as "gatekeepers" in this area. Although defense lawyers often speak of the risk that the government will put words in a cooperator's mouth, I think the greater risk is that a "cooperating" defendant will disclose as little as possible about himself and his associates. Prosecutors and agents are far more likely to discern such shading and deception than are judges, but actually proving that information was withheld can be difficult indeed. A rule allowing a defendant to force the government to take its claim about his lack of candor to a judge thus gives the defendant bargaining power that serves neither the truthfinding process nor sentencing equity.

\section{Conclusion}

I would be quite surprised if most readers agree with all the points I have made here. Because the exchange of cooperation for sentencing leniency is under-regulated and never the subject of systematic empirical investigation, the views of every actor or former actor in the system on this issue will be based on personal experience or anecdote. So while I think all can agree that any system allowing such ex- changes will undermine our commitment to a sentencing regime based on moral desert and proportionality, assessments of whether the benefits from the current cooperation system justify the costs will diverge widely.

Under the ancient English common law practice of "approvement," an accused felon who implicated an accomplice would win a complete pardon upon the accomplice's conviction. ${ }^{17}$ We have made some progress in confronting the inequities of such a system. But not much.

\section{NOTES}

${ }^{1}$ The recent unraveling of the El Rukn cases in Chicago dramatize what can happen when a prosecution team gets too close to its cooperating witnesses. See United States $v$. Griffin, 856 F. Supp. 1293 (N.D. Ill. 1994); United States $v$. Boyd, 833 F. Supp. 1277 (N.D.Ill. 1993), aff'd, 55 F.3d 239 (7th Cir. 1995); United States v. Andrews, 824 F. Supp. 1273 (N.D.Il. 1993); United States v. Burnside, 824 F. Supp. 1215 (N.D.Ill. 1993).

${ }^{2}$ See United States v. Ford, 99 U.S. 594, 599 (1878) ("The Whiskey Cases") ("Courts of justice everywhere agree that the established usage is that an accomplice duly admitted as a witness in a criminal prosecution against his associates in guilt, if he testifies fully and fairly, will not be prosecuted for the same offense....").

${ }^{3}$ See Daniel C. Richman, Cooperating Clients, 56 Ohio St. L. J. 69, 83-84 (1995); Richard C. Donnelly, Judicial Control of Informants, Spies, Stool Pigeons, and Agent Provocateurs, 60 Yale L. J. 1091, 1093 (1951).

${ }^{4}$ See Melendez v. United States, 64 U.S.L.W. 4525 (U.S. June 17,1996 ) (government may move under $\$ 5 \mathrm{~K} 1.1$ for court to depart below guideline range without necessarily moving under $\$ 3553$ (e) for departure below statutory minimum).

${ }^{5}$ See United States v. Brigham, 977 F.2d 317, 318 (7th Cir. 1992) (characterizing this result as "inverted sentencing"); United States v. Griffin, 17 F.3d 269, 274 (8th Cir. 1994) (Bright, J., dissenting) ("What kind of criminal justice system rewards the drug kingpin or near-kingpin who informs on all the criminal colleagues he has recruited, but sends to prison for years and years the least knowledgeable or culpable conspirator, one who knows very little about the conspiracy and is without information for the prosecutors?").

${ }^{6}$ Richman, supra note 3 , at 122-24.

'This point is developed in more detail in Richman, supra note 3 .

${ }^{8}$ Judges have been allowed considerable sentencing discretion once the government has made its motion, see United States $v$. Johnson, 33 F.3d 8, 9-10 (5th Cir. 1994) (reversing because sentencing judge may have accepted government's limited departure recommendation withnut exercising his independent judgment and discretion); see also Bruce M. Selya \& John C. Massaro, The Illustrative Role of 


\section{DANIEL C. RICHMAN}

Substantial Assistance Departures in Combatting UltraUniformity, 35 B.C. L. Rev. 799, 825-35 (1994), but they have been counseled to give "substantial weight" "to the government's evaluation of the extent of a defendant's assistance," U.S.S.G. $\$ 5 \mathrm{~K} 1.1, \mathrm{cmt}$. n.3, and almost inevitably will defer on such a fact-bound matter.

${ }^{9}$ Wade v. United States, 112 S. Ct. 1840 (1992).

${ }^{10}$ See Richman, supra note 3, at 101-02. A minority of circuits have demanded that the government act in "good faith" where there is such a contractual provision, see id. at 103 (citing cases), but this standard still leaves the government considerable room to rationalize a dubious, or even a bad faith, refusal to make a "substantial assistance" motion.

${ }^{11}$ See Stanley Marcus, Substantial Assistance Motions: What Is Really Happening?, 6 Fed. Sent. R. 6-8 (1993).

${ }^{12}$ See Ilene H. Nagel \& Stephen J. Schulhofer, A Tale of. Three Cities: An Empirical Study of Charging and Bargaining Practices Under the Federal Sentencing Guidelines, 66 S. Cal. L. Rev. 501, 531 (1992).

${ }^{13}$ See Bruce H. Kobayashi, Deterrence With Multiple Defendants: An Explanation for "Unfair" Plea Bargains, 23 Rand J. Econ. 507, 508 (1992) (arguing that leaving most culpable defendant with lowest sentence can maximize deterrence because increase in penalties placed on subordinates will more than outweigh any decrease in penalty of ringleader).
${ }^{14}$ The effects of cooperation on specific deterrence is also an open question. Certainly, a cooperator will find it difficult to return to the same criminal community that he snitched on. However, anecdotal evidence supports the intuition that the person who found it easy to escape severe sanctions for serious crimes simply by cooperating will take the risk of future prosecution more lightly.

I recall that after a defendant who cooperated in a major narcotics case had received a comparatively light sentence, the other Assistant on the case and I lightly told him that we hoped he would never return to the courthouse under such circumstances. He assured us: "You won't see me again. ... Unless it's for that white collar stuff."

${ }^{15}$ See Victor Navasky, Naming Names (1980). But see Malachi L. Harney \& John C. Cross, The Informer in Law Enforcement 17-20 (2d ed. 1968) (former federal agents ascribe unpopularity of informants to fact that "Communist conspiracy [had] launched an all-out attack on the informer as an institution").

${ }^{16}$ See Jack B. Weinstein, A Trial Judge's Reflections on Departures from the Federal Sentencing Guidelines, 4 Fed. Sent. R. 6 (July-Aug. 1992).

${ }^{17}$ See 4 William Blackstone, Commentaries *330; 2 Matthew Hale, History of the Pleas of the Crown, 226-35 (S. Emlyn ed. 1736); see also Albert W. Alschuler, Plea Bargaining and Its History, 79 Colum. L. Rev. 1, 14 (1979). 